\title{
Thermosensitive Magnetic Nanoparticles for Self-Controlled Hyperthermia Cancer Treatment
}

\section{Karen S. Martirosyan*}

Department of Physics and Astronomy, University of Texas at Brownsville, USA
Magnetic nanoparticles show remarkable phenomena such as superparamagnetism, high field irreversibility and high saturation magnetization [1]. The study of magnetic nanoparticles has been a very active research field due to many important applications such as drug delivery, imaging and hyperthermia cancer treatment [2]. Hyperthermia has been used for many years to treat a wide variety of tumors in patients and used as well as an adjunct to cancer radiotherapy or chemotherapy $[3,4]$. Its use is based on the fact that tumor cells are more sensitive to temperature in the range of $42-45^{\circ} \mathrm{C}$ (which yields necrosis, coagulation, or carbonization) than normal tissue cells. This temperature range has become critical for cancer treatment due to damaging the cancerous cells without altering the healthy cells by selective heating (up to $45^{\circ} \mathrm{C}$ ) and controlling heating rate and time.

Basically, hyperthermia increases perfusion and oxygenation of neoplastic hypoxic cells, which are more resistant to ionizing radiation than normal cells [5]. Moreover, increased tumor tissue perfusion facilitates the absorption of chemotherapeutic drugs through cell membrane without being more toxic [6-8]. As a result, the action of combination of hyperthermia with radiotherapy or chemotherapy becomes more efficient. Consequently, hyperthermia allows reducing of tumors resistant to various chemotherapeutic drugs such as doxorubicin, cisplatin, bleomycin, nitrosoureas, and cyclophosphamide. It has been demonstrated that hyperthermia also has an anti-angiogenic action and an immunotherapeutic role, due to thermal shock proteins, which are produced by stressed tumor cells $[9,10]$. This method has found clinical application mostly in Europe and Asia $[4,8]$. While in the United States, microwave hyperthermia in conjunction with radiation has received approval from the Food and Drug Administration (FDA), it still remains mostly as an experimental method due to possible overheating and necrosis of normal tissue $[11,12]$. There is an urgent need for development of new hyperthermia heating agents and treatment methodologies that will be more effective than those currently available and help to unlock the full potential of the technology that can have a significant impact on management of cancer patients. Thus, it is of paramount importance to develop new nanostructured media, which would enable selective heating of tumor cells and vasculature avoiding excessive damage to healthy tissue structures.

Magnetic fluids based on iron oxide $\left(\mathrm{Fe}_{3} \mathrm{O}_{4}\right)$, stabilized by biocompatible surfactants are typically used as heating agent in magnetic hyperthermia [13,14]. In the presence of AC magnetic field, magnetic nanoparticles show three different types of losses - Hysteresis, $\mathrm{Ne}^{\prime} \mathrm{el}$, and Brownian, which are responsible for heat generation. However, significant limitations of using commercial available magnetic nanoparticles are non-selectivity and overheating of surrounding normal tissues. For most nanoparticles suggested so far for cancer hyperthermia treatment, uniform controlled induction heating and selectivity remain as major challenges.

There is increasing number of research articles for self-controlled hyperthermia and development of nanoparticles with Curie Temperature $\left(\mathrm{T}_{\mathrm{c}}\right)$ in the range of $45-50^{\circ} \mathrm{C}$ that are not affected by alternating magnetic fields above $50^{\circ} \mathrm{C}$ in order to prevent overheating of normal cells [15-26]. Various nanoparticles were synthesized using physical as well as chemical methods. For example, ultrafine alumina coated particles of substituted ferrite $\mathrm{Co}_{1-\mathrm{x}} \mathrm{Zn}_{\mathrm{x}} \mathrm{Fe}_{2} \mathrm{O}_{4}$ and yttriumiron garnet $\mathrm{Y}_{3} \mathrm{Fe}_{5-\mathrm{x}} \mathrm{Al}_{\mathrm{x}} \mathrm{O}_{12}$ have been proposed to tailor $\mathrm{T}_{c}$ at $\sim 50^{\circ} \mathrm{C}$ [16]. Copper nickel (CuNi) alloy nanoparticles with varying $\mathrm{T}_{c}$ from 40 to $60^{\circ} \mathrm{C}$ were synthesized by several techniques [17]. In vitro and in vivo animal experiments have demonstrated the feasibility of the temperature-controlled heating of the tissue, laden with the particles, by an external alternating magnetic field. Nickel-Chromium $\left(\mathrm{Ni}_{1}\right.$ ${ }_{x} \mathrm{Cr}_{\mathrm{x}}$ ) particles with varying compositions have been investigated as thermoseeds for use in localized self controlled hyperthermia treatment of cancer [18]. A series of Ni-Cr alloys, have been prepared to find the specific composition that has Curie temperature in range of $43-44^{\circ} \mathrm{C}$. The samples were cast by arc melting technique then annealed at $850^{\circ} \mathrm{C}$ for 5 hours in sealed quartz tubes. The Curie temperatures of the alloys decreased almost linearly with increasing $\mathrm{Cr}$ concentration from 4.54 to 5.9 wt \%. The results showed that $\mathrm{Ni}_{1-\mathrm{x}} \mathrm{Cr}_{\mathrm{x}}$ alloys might be good candidates for self controlled magnetic hyperthermia applications.

Structural and magnetic properties have been studied for $\mathrm{Gd}_{5}\left(\mathrm{Si}_{1-}\right.$ $x \mathrm{Ge} x)_{4}$ and $\left(\mathrm{Gd}_{1-} x R x\right)_{5} \mathrm{Si}_{4}$ series, with $R=\mathrm{Ce} \mathrm{Nd}, \mathrm{Er}$, and Ho, in the context of their use as magnetic materials in the self-controlled hyperthermia treatment of cancer [19]. The study shows that these materials have high magnetization values and their magnetic ordering temperatures can be varied linearly over a broad range by adjusting the composition of the constituent elements. The high magnetization and optimal $\mathrm{T}_{c}$ values of these composites meets self-controlled hyperthermia requirements.

$\mathrm{La}-\mathrm{Ag}$ and $\mathrm{La}-\mathrm{Na}$ perovskite manganites were proposed [20] as smart mediators for self-controlled isothermal heating in magnetic hyperthermia. It shows that dissipation of the alternating magnetic field energy causes heating of aqueous suspensions to terminate at $42-48^{\circ} \mathrm{C}$ without external temperature control. Ferromagnetic $\mathrm{La}_{0.73} \mathrm{Sr}_{0.27} \mathrm{MnO}_{3}$ nanoparticles $(20-100 \mathrm{~nm})$ showed saturation magnetization $\sim 38 \mathrm{emu} / \mathrm{g}$ at $20 \mathrm{kOe}$ with $\mathrm{T}_{\mathrm{C}}$ value of $45^{\circ} \mathrm{C}$ [21]. Unaggregated $\mathrm{La}_{0.8} 2 \mathrm{Sr}_{0.18} \mathrm{MnO}_{3+\delta}$ perovskite nanoparticles with a mean crystallite size of $22 \mathrm{~nm}$ were successfully synthesized through an aqueous combustion synthesis, which takes advantage of exothermic, fast and self-sustaining chemical reactions between metal nitrates and glycine [22]. Fast calcination and milling process were used to

${ }^{*}$ Corresponding author: Karen S. Martirosyan, Department of Physics and Astronomy, University of Texas at Brownsville, 80 Fort Brown, SETB 2.258, Brownsville, TX, 78520, USA, E-mail: karen.martiroyan@utb.edu

Received July 10, 2012; Accepted July 10, 2012; Published July 12, 2012

Citation: Martirosyan KS (2012) Thermosensitive Magnetic Nanoparticles for Self-Controlled Hyperthermia Cancer Treatment. J Nanomed Nanotechol 3:e112. doi:10.4172/2157-7439.1000e112

Copyright: $\odot 2012$ Martirosyan KS. This is an open-access article distributed under the terms of the Creative Commons Attribution License, which permits unrestricted use, distribution, and reproduction in any medium, provided the original author and source are credited. 
enhance crystallinity of the nanoparticles and their desaggregation. The heating experiments of magnetic fluid suspended $\mathrm{La}_{0.8} 2 \mathrm{Sr}_{0.18} \mathrm{MnO}_{3+\delta}$ nanoparticles in AC magnetic field demonstrated that the particles can be used for self-controlled hyperthermia application, considering their maximum heating temperature $\sim 43^{\circ} \mathrm{C}$. Recently, it was shown that complex ferrites nanoparticles with formula $\mathrm{Mg}_{1+x} \mathrm{Fe}_{2-2 \mathrm{x}} \mathrm{Ti}_{\mathrm{x}} \mathrm{O}_{4}$, (where $0 \leq \mathrm{x} \leq 0.5$ ) can be meet self-controlled hyperthermia requirements with $\mathrm{T}_{\mathrm{c}}$ in range of $45-50^{\circ} \mathrm{C}$ [23-24]. Furthermore, authors [25] confirmed that Curie temperature for $\mathrm{Zn}$ doped $\mathrm{Mn}$-ferrite, $\mathrm{Mn}_{1-\mathrm{x}} \mathrm{Zn}_{\mathrm{x}} \mathrm{O}$ and the $\mathrm{Gd}$ doped $\mathrm{Zn}$-ferrite, $\mathrm{ZnGd}_{\mathrm{x}} \mathrm{Fe}_{2-\mathrm{x}} \mathrm{O}_{4}$ nanoparticles can be tuned to the optimum temperature of $43^{\circ} \mathrm{C}$. The $\mathrm{Mg}$ - $\mathrm{Fe}-\mathrm{Ti}$ compositions are very promising, since all the elements biocompatible. Magnetic nanocomposite $\mathrm{Ni}_{0.2} \mathrm{Ca}_{0.8} \mathrm{Gd}_{0.08} \mathrm{Fe}_{1.92} \mathrm{O}_{4}$ encapsulated by poly vinyl alcohol and synthesized by a two steps chemical reaction including solgel combustion and solvent casting technique also can be applicable for self controlled hyperthermia [26].

Thus, the magnetic materials with Curie temperature $\sim 45^{\circ} \mathrm{C}$, having sufficient biocompatibility are the best candidates for effective cancer hyperthermia treatment to avoid overheating. Because of unique capability of turning on and off the magnetic properties depending on temperature, the tumors will be continuously heated at a self-controlled temperature equal to the Curie temperature of the magnetic nanoparticles. This approach will allow to heat the tumor cells and vasculature selectively and to prevent overheating with subsequent damage to neighboring healthy tissues. Additionally, the self-controlled method might allow in situ MRI monitoring and selective hyperthermic therapy.

\section{References}

1. Lu AH, Salabas EL, Schuth F (2007) Magnetic nanoparticles: synthesis, protection, functionalization, and application. Angew Chem Int Ed Engl 46: $1222-1244$.

2. Pankhurst QA, Connolly J, Jones SK, Dobson J (2003) Applications of magnetic nanoparticles in biomedicine. J Phys D Appl Phys 36: R167-181.

3. Moroz P, Jones SK, Gray BN (2002) Magnetically mediated hyperthermia: current status and future directions. Int J Hyperthermia 18: 267-284.

4. Seppa N (2005) Microwavable cancers: Heat plus radiation shrinks some tumors. Sci News 167: 294.

5. Burgman P, Nusenzweig A, Li GC, Vernon CC, Sahu SK, et al. (1995) Thermoradiotherapy \& Thermochemotherapy. Biology, Physiology \& Physics.

6. Kampinga $\mathrm{HH}$ (2006) Cell biological effects of hyperthermia alone or combined with radiation or drugs: a short introduction to newcomers in the field. Int J Hyperthermia 22: 191-196.

7. Dayanc BE, Beachy SH, Ostberg JR, Repasky EA (2008) Dissecting the role of hyperthermia in natural killer cell mediated anti-tumor responses. Int $J$ Hyperthermia 24: 41-56.

8. Van der Heijden G, Kiemeney LA, Gofrit ON, Nativ O, Sidi A, et al. (2004) Preliminary European results of local microwave hyperthermia and chemotherapy treatment in intermediate or high risk superficial transitional cell carcinoma of the bladder. Eur Urol 46: 65-71.

9. Nakano H, Kurihara K, Okamoto M, Toné S, Shinohara K (1997) Heat-induced apoptosis and p53 in cultured mammalian cells. Int J Radiat Biol 71: 519-529.

10. Ito A, Saito H, Mitobe K, Minamiya $Y$, Takahashi N, et al. (2009) Inhibition of heat shock protein 90 sensitizes melanoma cells to thermosensitive ferromagnetic particle-mediated hyperthermia with low Curie temperature. Cancer Sci 100: 558-564.

11. Bansal R (2005) Battling Cancer: The latest on microwave hyperthermia. IEEE microwave magazine 6: 32-34.

12. Jones EL, Oleson JR, Prosnitz LR, Samulski TV, Vujaskovic Z, et al. (2005) Randomized trial of hyperthermia and radiation for superficial tumors. J Clin Oncol 23: 3079-3085.
13. Bagaria HG, Johnson DT (2005) Transient solution to the bioheat equation and optimization for magnetic fluid hyperthermia treatment. Int J Hyperthermia 21: $57-75$.

14. R. Hergt, Andra W, d'Ambly CG, Hilger I, Kaiser WA, et al. (1998) Physical limits of hyperthermia using magnetite fine particles. IEEE Trans Magn 34: 3745-3754.

15. Saito H, Mitobe K, Ito A, Sugawara Y, Maruyama K, et al. (2008) Self-regulating hyperthermia induced using thermosensitive ferromagnetic material with a low Curie temperature. Cancer Sci 99: 805-809.

16. Giri J, Ray A, Dasgupta S, Datta D, Bahadur D (2003) Investigation on Tc tuned nano particles of magnetic oxides for hyperthermia applications. Biomed Mater Eng 13: 387-399.

17. Kuznetsov AA, Leontiev VG, Brukvin VA, Vorozhtsov GN, Kogan BY, et al. (2007) Local radiofrequency-induced hyperthermia using CuNi nanoparticles with therapeutically suitable Curie temperature. J Magn Magn Mater 311: 197203.

18. Akin $Y$, Obaidat IM, Issa B, Haik $Y$ (2009) $\mathrm{Ni}_{1-x} \mathrm{Cr}_{x}$ alloy for self controlled magnetic hyperthermia. Crystal Research and Technology 44: 386-390.

19. Ahmad SN, Shaheen SA (2009) Optimization of $(\mathrm{Gd})_{5} \mathrm{Si}_{4}$ based materials: A step toward self-controlled hyperthermia applications. J Appl Phys 106: 064701.

20. Shlyakhtin OA, Leontiev VG, Oh YJ, Kuznetsov AA et al. (2007) New manganite-based mediators for self-controlled magnetic heating. Smart Materials \& Structures 16: N35-N39.

21. Prasad NK, Rathinasamy K, Panda D, Bahadur D (2008) $T_{C}$-Tuned biocompatible suspension of $\mathrm{La} 0.73 \mathrm{Sr} 0.27 \mathrm{MnO} 3$ for magnetic hyperthermia. J Biomed Mater Res B Appl Biomater 85: 409-416.

22. Epherre R, Duguet E, Mornet S, Emil P, Stéphanie L, et al. (2011) Manganite perovskite nanoparticles for self-controlled magnetic fluid hyperthermia: about the suitability of an aqueous combustion synthesis route. J Mater Chem 21 4393-4401.

23. Shimizu T, Asano H, Matsui M (2007) Ferromagnetic exchange interaction and Curie temperature of $\mathrm{Mg}_{1+\mathrm{x}} \mathrm{Fe}_{2-2 \mathrm{x}} \mathrm{Ti}_{\mathrm{x}} \mathrm{O}_{4}(\mathrm{x}=0-0.5)$ system. $\mathrm{J}$ Magn Magn Mater 310: 1835-1837.

24. Martirosyan KS (2001) Thermosensitive nanostructured media for imaging and hyperthermia cancer treatment. Bulletin of the American Physical Society 56: 1.

25. Apostolov AT, Apostolova IN, Wesselinowa JM (2011) MO. $\mathrm{Fe}_{2} \mathrm{O}_{3}$ nanoparticles for self-controlled magnetic hyperthermia. J Appl Phys 109: 083939.

26. Prasad AS, Dolia SN (2012) Gd substituted NiCa ferrite/poly vinyl alcohol nanocomposite. J Magn Magn Mater 324: 869-872. 